\title{
Dietary Habits of University Students Living at Home or at University Dorm: A Cross-Sectional Study in Saudi Arabia
}

\author{
Etab S. Alghamdi ${ }^{1}$, Morooj S. Farrash ${ }^{1}$, Marwan A. Bakarman ${ }^{2} \&$ Abdel Moniem Mukhtar ${ }^{2}$ \\ ${ }^{1}$ Food and Nutrition Department, Faculty of Home Economics, King Abdulaziz University, Jeddah, Saudi Arabia \\ ${ }^{2}$ Family and Community Medicine Department, Rabigh Faculty of Medicine, King Abdulaziz University, Jeddah, \\ Saudi Arabia \\ Correspondence: Etab S. Alghamdi, Food and Nutrition Department, Faculty of Home Economics, King \\ Abdulaziz University, Jeddah, P. O. Box: 2929 Jeddah 21461, Saudi Arabia. Tel. 966-554-887-880. E-mail: \\ asalghamdy2@kau.edu.sa
}

Received: July 24, 2018 Accepted: August 20, 2018 Online Published: September 3, 2018

doi:10.5539/gjhs.v10n10p50 URL: https://doi.org/10.5539/gjhs.v10n10p50

\begin{abstract}
Background: Living with the family at home or away from it at the university dorm might affect the behavior of students, including their dietary habits. The aim of this study was to assess the differences in dietary habits between Saudi undergraduate students living with their families and those living at university dorms.
\end{abstract}

Methods: A cross-sectional study done at six Saudi universities. We recruited 354 undergraduate students. A self-administered structured questionnaire was used to collect data on socio-demographic characteristics, dietary habits, physical activities, perceived body weight and gastro-intestinal symptoms. Differences between students living at home with their families and those living on campus at university dorms were assessed using the chi-squared test.

Results: Three quarters of our sample were female (77\%). Almost $80 \%$ of the students lived with their families. Change in dietary habits after joining the university was significantly more common among students living at university dorms $(\mathrm{p}<0.001)$. Major changes in dietary habits were found in $68.6 \%$ of students living at home with their families and in $31.4 \%$ of those living at university dorms. Moreover, we found significant difference between students living with their families and those living at university dorms, regarding place of breakfast $(\mathrm{p}=0.003)$, place of lunch $(\mathrm{p}<0.001)$, place of dinner $(\mathrm{p}=0.002)$ and perceived body weight $(\mathrm{p}=0.018)$.

Conclusions and Recommendations: Most of the students were living with their families. However, students living at university dorms were at higher risk of unhealthy change in their dietary habits. More nutritional interventions to enhance the health of students should be introduced.

Keywords: dietary habits, university students, university dorms, Saudi Arabia

\section{Introduction}

Unhealthy diet and physical inactivity are leading global causes of death and morbidities (Miller, 2017; Lear, 2017). University students undergo a life transition that often results in unhealthy dietary behaviors and unfavorable increase in body weight (Wilson, 2017). Students who leave their families should self-organize the purchase and preparation of food and this might affect their dietary habits negatively (Papadaki, 2007). Several factors such as limited time, academic stress and lack of money might play a role in this regard.

Studies showed that the most common unhealthy eating habits in university students were high consumption of sugar-sweetened drinks, butter and saturated fats; skipping breakfast, and midnight munching (Yahia, 2008; Al-Rethaiaa, 2010). College students living away from home were highly vulnerable to imbalanced diet and malnutrition, attraction to a new lifestyle, making their own food choices and irregular daily routines (Parmar, 2017). Unhealthy food choices of university students could affect weight management and lead to overweight or obesity (Peltzer, 2014).

Skipping breakfast is an unhealthy dietary habit affecting students' health. For provision of energy for the brain and to improve learning ability, breakfast is the most important meal of the day. Moreover, academic stress, especially during exam and excessive homework times, may cause some students to eat excessively or less than 
normal (Ackuaku-Dogbe, 2014).

Many factors may influence food choices including the color, shape, temperature, aroma and flavor of food. Food availability and accessibility can also have an effect on food choices of university students, especially those living at university dorms. Food costs can affect students' choices; often healthy foods have a higher price than fast and processed foods (CLIK, 2018).

The aim of this study was to assess the differences in dietary habits between Saudi undergraduate students living with their families and those living at university dorms.

\section{Methods}

We followed the" Strengthening the Reporting of Observational Studies in Epidemiology" (STROBE) guidelines for reporting our study methods and results (von Elm, 2007).

\subsection{Study Design}

We conducted a cross-sectional study between September 2017 and February 2018.

\subsection{Study Participants}

We recruited 354 undergraduate students at six Saudi Universities (King Abdulaziz University, King Khalid University, King Saud University, King Faisal University, Umm Al-Qura University, and King Fahd University). We used flyers, announcements on University notice boards and social media to invite students to participate in the study. We excluded students who suffered from gastro intestinal problems.

\subsection{Study Setting and Location}

Our study was a multi-center study including six universities from four different regions in Saudi Arabia.

\subsection{Data Collection Method and Study Variables}

We used a self-administered structured questionnaire developed and used by Bagordo and colleagues (Bagordo, 2013). It included questions on socio-demographic characteristics, dietary habits, physical activities, perceived body weight and gastro-intestinal symptoms.

\subsection{Sample Size}

Our primary outcome was change in dietary habits after joining the university. Prior data showed that changes in dietary habits after joining the university affected $23 \%$ of university students ${ }^{12}$. Assuming the same rate of change in our study, we needed to recruit at least 272 students to estimate changes in dietary habits with a precision of $5 \%$. We succeeded to recruit a higher number of eligible students in our study sample $(\mathrm{n}=354)$.

\subsection{Statistical Analysis}

We used frequencies and absolute numbers to describe categorical variables and mean and standard deviation to describe continuous variables. Difference between students living with their families and those living at university dorms were assessed using the chi-squared test. A p value less than 0.05 was considered significant. We used SPSS version 21.0 to conduct all statistical analyses.

\section{Results}

We included 354 undergraduate students in our study. Seventy-seven percent $(n=273)$ of them were female. The mean age $( \pm$ SD) of the students living with their families was $25 \pm 5.3$ years and of those living at university dorms was $22 \pm 2.4$ years. $80.5 \%(n=285)$ of the students lived with their families and $19.5 \%(n=69)$ lived in university dorms.

As shown in Table 1, the change in eating habits after joining the university was significantly more common among students living at university dorms than among students living at home with family $(\mathrm{p}<0.001)$. Major changes in dietary habits were found in $53.6 \%$ of students living at university dorms and in $28.4 \%$ of those living at home with their families. 
Table 1. Differences between Students Living at University Dorm and Students Living at Home with Family in the Perceived Change in Eating Habits $(n=354)$

\begin{tabular}{|c|c|c|c|c|c|}
\hline \multirow[b]{2}{*}{ Variable } & \multirow[b]{2}{*}{ Category } & \multicolumn{3}{|l|}{ Living Place } & \multirow[b]{2}{*}{ Pvalue* } \\
\hline & & $\begin{array}{l}\text { At } \\
\text { Dorm } \\
n=69\end{array}$ & $\begin{array}{l}\text { At Home with } \\
\text { Family } \\
\mathbf{n}=\mathbf{2 8 5}\end{array}$ & $\begin{array}{l}\text { Total } \\
n=354(100 \%)\end{array}$ & \\
\hline \multirow{3}{*}{$\begin{array}{l}\text { Change in Eating } \\
\text { Habits. No. }(\%)\end{array}$} & Yes, a lot & $37(53.6)$ & $81(28.4)$ & $118(33.3)$ & \\
\hline & Yes, but not much & $23(33.3)$ & $133(46.7)$ & $156(44.1)$ & $<0.001$ \\
\hline & No, not at all & $9(13.0)$ & $71(24.9)$ & $80(22.6)$ & \\
\hline
\end{tabular}

There was significant difference between students living at home with their families and those living at university dorms in place of breakfast $(p=0.003)$, place of lunch $(p<0.001)$ and place of dinner $(p=0.002)$. Students living at home with their families ate their breakfast, lunch and dinner significantly more often at home than students that lived at university dorms. The latter ate these meals at their rooms on the university campus. One half (49.8\%) of the students living with their families took breakfast at home and $31.9 \%$ of those living at university dorms took breakfast at room on the university campus. Three quarter (75.4\%) of the students living with their families took lunch at home and $40.6 \%$ of those living at university dorms took lunch at room in the university campus. Whereas $71.9 \%$ of the students living with their families took dinner at home and $52.2 \%$ of those living at university dorms took dinner at room on the university campus.

Interestingly, $15.8 \%$ of students living at home with their families and $31.9 \%$ of those living at university dorms skipped breakfast, also $28.1 \%$ of students living at home with their families and $47.8 \%$ of those living at university dorms skipped dinner (see Table 2).

Table 2. Differences between Students Living at University Dorm and Students Living at Home with Family in Dietary Habits $(\mathrm{n}=354)$

\begin{tabular}{|c|c|c|c|c|c|}
\hline \multirow[b]{2}{*}{ Variable } & \multirow[b]{2}{*}{ Category } & \multicolumn{3}{|l|}{ Living Place } & \multirow[b]{2}{*}{ P Value* } \\
\hline & & $\begin{array}{l}\text { At University Dorm } \\
\mathrm{N}=69 \\
(\mathbf{1 0 0 \%})\end{array}$ & $\begin{array}{l}\text { At Home with Family } \\
\mathrm{N}=\mathbf{2 8 5} \\
(\mathbf{1 0 0} \%)\end{array}$ & $\begin{array}{l}\text { Total } \\
\mathrm{N}=\mathbf{3 5 4} \\
(\mathbf{1 0 0 \%})\end{array}$ & \\
\hline \multirow{3}{*}{$\begin{array}{l}\text { Place of Breakfast } \\
\text { No. }(\%)\end{array}$} & I do not eat it & $22(31.9)$ & $45(15.8)$ & $67(18.9)$ & \multirow{3}{*}{0.003} \\
\hline & At university & $25(36.2)$ & $98(34.4)$ & $123(34.7)$ & \\
\hline & At home or room & $22(31.9)$ & $142(49.8)$ & $164(46.3)$ & \\
\hline \multirow{3}{*}{$\begin{array}{l}\text { Place of Lunch } \\
\text { No. (\%) }\end{array}$} & At restaurant & $18(26.1)$ & $27(9.5)$ & $45(12.7)$ & \multirow{3}{*}{$<0.001$} \\
\hline & At university & $23(33.3)$ & $43(15.1)$ & $66(18.6)$ & \\
\hline & At home or room & $28(40.6)$ & $215(75.4)$ & $243(68.6)$ & \\
\hline Place of Dinner & I do not eat it & $33(47.8)$ & $80(28.1)$ & $113(31.9)$ & \multirow{2}{*}{0.002} \\
\hline No. $(\%)$ & At home or room & $36(52.2)$ & $205(71.9)$ & $241(68.1)$ & \\
\hline
\end{tabular}

* Results of chi-squared test.

There was significant difference between students living at home with their families and those living at university dorms in perceived body weight $(\mathrm{p}=0.018)$. Students living at home with their families perceived their body weight significantly more obese than students living at university dorms. Almost $68.1 \%$ of the students living at university dorms perceived themselves obese comparing to $49.1 \%$ of the students living at home with their families. There was no significant difference between students living at home with their families and those living at university dorms in sport activities ( $\mathrm{p}=0.342)$ and gastro-intestinal symptoms in the last year $(\mathrm{p}=0.414)$. However, daily sport activities were reported in $8.1 \%$ of the students living at home with their families and $13.0 \%$ of the students living at university dorms. Gastro-intestinal symptoms in the last year were reported in $32.6 \%$ of the 
students living at home with their families and $29.0 \%$ of the students living at university dorms (see Table 3).

Table 3. Differences between Students Living at University Dorm and Students Living at Home with Family in Perceived Weight, Physical Activities and Gastro-Intestinal Symptoms $(\mathrm{n}=354)$

\begin{tabular}{|c|c|c|c|c|c|}
\hline \multirow[b]{2}{*}{ Variable } & \multirow[b]{2}{*}{ Category } & \multicolumn{3}{|l|}{ Living Place } & \multirow[b]{2}{*}{$\begin{array}{l}\mathbf{p} \\
\text { Value }\end{array}$} \\
\hline & & $\begin{array}{l}\text { At University Dorm } \\
\mathrm{N}=69\end{array}$ & $\begin{array}{l}\text { At Home with Family } \\
\mathbf{N}=\mathbf{2 8 5}\end{array}$ & $\begin{array}{l}\text { Total } \\
\mathrm{N}=\mathbf{3 5 4} \\
(\mathbf{1 0 0 \% )}\end{array}$ & \\
\hline \multirow{3}{*}{ Perceived Weight } & Obese & $47(68.1)$ & $140(49.1)$ & $187(52.8)$ & \multirow{3}{*}{0.018} \\
\hline & Overweight & $14(20.3)$ & $95(33.3)$ & $109(30.8)$ & \\
\hline & Normal weight & $8(11.6)$ & $50(17.5)$ & $58(16.4)$ & \\
\hline \multirow{3}{*}{ Sport Activities } & No sport & $38(55.1)$ & $153(53.7)$ & $191(54.0)$ & \multirow{3}{*}{0.342} \\
\hline & 1 to 3 times weekly & $22(31.9)$ & $109(38.2)$ & $131(37.0)$ & \\
\hline & Every day & $9(13.0)$ & $23(8.1)$ & $32(09.0)$ & \\
\hline \multirow{3}{*}{$\begin{array}{l}\text { GI Symptoms in } \\
\text { the Last Year }\end{array}$} & Yes & $20(29.0)$ & $93(32.6)$ & $113(31.9)$ & \multirow{3}{*}{0.414} \\
\hline & I do not remember & $13(18.8)$ & $68(23.9)$ & $81(22.9)$ & \\
\hline & No & $36(52.2)$ & $124(43.5)$ & $160(45.2)$ & \\
\hline
\end{tabular}

* Results of chi-squared test.

\section{Discussion}

This study examined the difference in dietary habits between students living at home and those living at university dorms. Our study showed that most of the Saudi students were living with their families and had not encountered considerable change in their dietary habits after joining the university. However, students living at university dorms were at higher risk of unhealthy change in their dietary habits after joining the university. Major changes in dietary habits were reported in almost half (53.6\%) of the students living at university dorms and in less than one third (28.4\%) of those living at home with their families. This was consistent with our finding that students living at home with their families ate their breakfast, lunch and dinner significantly more often at home than students that lived at university dorms. The latter ate these meals at their rooms on the university campus. Several previous studies showed similar results (Yahia, 2008; Al-Rethaiaa, 2010; Parmar, 2017). Moving away from home and family might be associated with significant negative changes in nutritional habits and students living away from home are often at higher risk of consuming fast-foods (Kattelmann, 2014). Therefore, we recommend introducing and monitoring nutritional interventions to enhance healthy dietary habits among students living at university dorms.

Interestingly, skipping breakfast was by far more common among students living at university dorm than among students living at home. We found that $15.8 \%$ of students living at home with their families and $31.9 \%$ of those living at university dorms skipped breakfast. This might be due to the fact that lectures and seminars at the universities start early in the morning and students living outside the university campus have less time for breakfast than students living on the campus (Deliens, 2016). Hence, we recommend providing easily accessible and healthy breakfast at university cafeterias for all students.

\section{Competing Interests Statement}

The authors declare that there are no competing or potential conflicts of interest.

\section{References}

Ackuaku-Dogbe, E. M., \& Abaidoo, B. (2014). Breakfast eating habits among medical students. Ghana Med J., 48(2), 66-70. https://doi.org/10.4314/gmj.v48i2.2

Al-Rethaiaa, A. S., Fahmy, A. E., \& Al-Shwaiyat, N. M. Obesity and eating habits among college students in Saudi Arabia: a cross sectional study. Nutr J., 9, 39. https://doi.org/10.1186/1475-2891-9-39

Bagordo, F., Grassi, T., Serio, F., Idolo, A., \& De Donno, A. Dietary habits and health among university students 
living at or away from home in southern Italy. Journal of Food and Nutrition Research, 52(3), 164-171.

Consolidated Library of Information and Knowledge (CLIK). (2018). 7. Factors Influencing Food Choices in Humans. Retrieved Mrach 6, 2018, from http://clik.dva.gov.au/reports-studies-research-papers-library/research-and-health-studies/animal-fat-australi an-diet/7-factors-influencing-food-choices-humans

Deliens, T., Van Crombruggen, R., Verbruggen, S., De Bourdeaudhuij, I., Deforche, B., \& Clarys, P. (2016). Dietary interventions among university students: A systematic review. Appetite, 105, 14-26. https://doi.org/10.1016/j.appet.2016.05.003

Kattelmann, K. K., Bredbenner, C. B., White, A. A., Greene, G. W., Hoerr, S. L., Kidd, T., et al. (2014). The effects of Young Adults Eating and Active for Health (YEAH): a theory-based Web-delivered intervention. $J$ Nutr Educ Behav., 46(6), S27-41. https://doi.org/10.1016/j.jneb.2014.08.007

Lear, S. A., Hu, W., Rangarajan, S., Gasevic, D., Leong, D., Iqbal, R., Casanova, A., et al. (2017). The effect of physical activity on mortality and cardiovascular disease in 130000 people from 17 high-income, middle-income, and low-income countries: the PURE study. Lancet, 390(10113), 2643-2654. https://doi.org/10.1016/S0140-6736(17)31634-3

Miller, V., Mente, A., Dehghan, M., Rangarajan, S., Zhang, X., Swaminathan, S., Dagenais, G., et al. (2017). Fruit, vegetable, and legume intake, and cardiovascular disease and deaths in 18 countries (PURE): a prospective cohort study. Lancet, 390(10107), 2037-2049. https://doi.org/10.1016/S0140-6736(17)32253-5

Papadaki, A., Hondros, G. A., Scott, J., \& Kapsokefalou, M. (2007). Eating habits of University students living at, or away from home in Greece. Appetite, 49(1), 169-176. https://doi.org/10.1016/j.appet.2007.01.008

Parmar, P., Damor, R., Modi, A., Patel, D., Godara, N., \& Kosambiya, J. (2017). Exploring the Dietary Habit of Medical Students' and their Perception about its Effect on Health. Indian Journal of Public Health Research \& Development, 8(1), 154-158. https://doi.org/10.5958/0976-5506.2017.00032.8

Peltzer, K., Pengpid, S., Samuels, T., Özcan, N., Mantilla, C., Rahamefy, O., Wong, M. et al. (2014). Prevalence of Overweight/Obesity and Its Associated Factors among University Students from 22 Countries. Int J Environ Res Public Health, 11(7), 7425-7441. https://doi.org/10.3390/ijerph110707425

von Elm, E., Altman, D. G., Egger, M., Pocock, S. J., Gøtzsche, P. C., \& Vandenbroucke, J. P. (2007). STROBE Initiative.The Strengthening the Reporting of Observational Studies in Epidemiology (STROBE) statement: guidelines for reporting observational studies. Lancet, 370(9596), 1453-7. https://doi.org/10.1016/S0140-6736(07)61602-X

Wilson, C. K., Matthews, J. I., Seabrook, J. A., Dworatzek, P. D. N. (2017). Self-reported food skills of university students. Appetite, 108, 270-276. https://doi.org/10.1016/j.appet.2016.10.011

Yahia, N., Achkar, A., Abdallah, A., \& Rizk, S. (2008). Eatinghabit and obesity among Lebanese university students. Nutr J, 7, 32. https://doi.org/10.1186/1475-2891-7-32

\section{Copyrights}

Copyright for this article is retained by the author(s), with first publication rights granted to the journal.

This is an open-access article distributed under the terms and conditions of the Creative Commons Attribution license (http://creativecommons.org/licenses/by/4.0/). 